\title{
Differential objects and other structural objects
}

\author{
Monica Alexandrina Irimia*
}

\begin{abstract}
Several recent accounts take adpositional differential marking to indicate those classes of DPs that require obligatory licensing (Case). Here, we examine data from Gujarati and Romanian where this analysis is harder to implement. The two languages exhibit structural DPs that are signaled via a preposition. But they also contain other structural objects which must be equally analyzed in terms of licensing, leaving the difference from the adpositional objects unexplained. The solution proposed builds on the idea of secondary licensing on the same DP, going back to Kayne's Generalization. The conclusion is that, at least in some languages, differential objects are classes that undergo an additional licensing operation.
\end{abstract}

Keywords. adpositional differential object marking; accusative; structural objects; licensing; dative

1. Introduction. The vast (descriptive and theoretical) literature on differential object marking (DOM) has revealed pervasive splits in the morpho-syntactic encoding of direct objects (Moravcsik 1978, Comrie 1979, 1981, Givón 1984, Croft 1988, 1990, Bossong 1991, 1998, Lazard 2001, Aissen 2003, de Swart 2007, Darlymple and Nikolaeva 2011, López 2012, a.o.). Cross-linguistically, objects containing certain features among which humanness (animacy), specificity, definiteness, etc. ${ }^{l}$ or a combination thereof tend to show more complex marking in the form of obligatory verbal agreement, case, an adposition, etc. Two typical examples come from HindiUrdu (Butt 1993, Mohanan 1994, Bhatt and Anagnostopolou 1996, a.o.) and Spanish (Ormazabal and Romero 2007, 2013, López 2012, a.o.). In these languages, certain types of DPs, such as proper names (1)a or definite animates (2)a require a postposition (which is homophonous with the dative marker). Hindi non-specific DPs (1)b, and Spanish inanimates (2)b, on the other hand, do not (usually) accept this type of marking:

(1) Hindi-Urdu
a. Ram-ne Jason-*(ko)
Ram-ERG Jason-DAT=DOM ${ }^{2}$
'Ram saw Jason.'
b. Ram ek kitab-(*ko)
$\operatorname{Ram}(\mathrm{M} . \mathrm{SG})$ one book(F.SG)-DAT=DOM
'Ram will read a book.'
dekh-aa.
see-PFV
(Bhatt and Anagnostopoulou 1996: ex. 1c)
paṛ $^{\mathrm{h}}$-egaa.
read-FUT.M.SG
(Butt 1993: 1b)

\footnotetext{
* First of all, I would like to thank the kind language consultants for their generosity with their time and their insight with respect to the data. I am also very grateful to Giuseppe Longobardi, András Bárányi, Anna Pineda, Víctor Acedo-Matellán, Cristina Guardiano, Laura Kalin, Rita Manzini, as well as several anonymous reviewers for their feedback and discussion on various points addressed in this paper. All errors and mistakes are my own. Author: Monica Alexandrina Irimia, University Modena and Reggio Emilia (irimiamo@ unimore.it).

${ }^{1}$ Or, more generally the objects that encode specifications at the higher end of Scales (Aissen 2003, a.o.):

Animacy Scale: $1 / 2>$ proper name $>3>$ human $>$ animate $>$ inanimate

Specificity/Definiteness Scale: pronoun $>$ name $>$ definite $>$ specific indefinite $>$ non-specific

2 Abbreviations are as follows: $\mathrm{ABS}=$ absolutive, $\mathrm{ACC}=$ accusative, $\mathrm{AUG}=$ augmented, $\mathrm{CL}=\mathrm{clitic}, \mathrm{DAT}=\mathrm{dative}$, $\mathrm{DEF}=$ definite, $\mathrm{DESID}=$ desiderative, $\mathrm{DOM}=$ differential object marking, $\mathrm{ERG}=$ ergative, $\mathrm{F}=$ feminine, $\mathrm{FUT}=$ future, $\mathrm{M}=\mathrm{mas}-$ culine, $\mathrm{N}=$ neuter, $\mathrm{PFV}=$ perfective, $\mathrm{PL}=$ plural, $\mathrm{PST}$.PRT=past participle, $\mathrm{SG}=$ singular.
} 
Spanish (Ormazabal and Romero 2013: ex. 1a, b)
a. He encontrado
have.1.SG find.PST.PRT
*(a)
la niña.
DAT=DOM the girl 'I have found the girl.'
b. He encontrado
have.1.SG find.PST.PRT

'I have found the book.'

In recent minimalist accounts adpositional differential marking of this type is generally understood as signalling a difference between categories that must undergo licensing (proper names, pronouns, specific definites, etc.) and categories that do not/cannot do so (Lochbihler 2012, López 2012, Ormazabal and Romero 2013, Wiltschko 2014, Levin 2017, Kalin to appear, a.o.). Nominals that are subject to licensing have an abstract requirement and must enter into a (phi-) relationship with functional heads in the clausal spine $(v, T, C$, etc.). The result of this mechanism is the overt realization of special encoding in the form of an adposition, agreement, case, etc. This short paper discusses two languages, namely Gujarati (Indo-Aryan) and Romanian (Romance), which appear to present some complications to the canonical licensing remarks mentioned above. The main problem is that in these languages there seem to be other classes of nominals which pass diagnostics indicating licensing. As illustrated in the next section, in Gujarati there are absolutives which trigger overt agreement even in the absence of the DAT postposition. Romanian, on the other hand, is different from Spanish, in that definite animates of the type in (2)a are possible without the accusative preposition. More generally, referential definites appear to be subject to licensing in the language, irrespective of animacy. It is proposed that (at least) in these languages, adpositional differential marking reflects an additional licensing operation on the same DP, which is subject to the constraint in (3):

(3) Adpositional differential marking: If a DP has more than one feature (of the same type) that requires valuation in the same domain, an additional licenser must be made available

The structure of the paper is as follows. Section (2) introduces the relevant data from Gujarati. Section (3) addresses the facts from Romanian. Section (4) evaluates three accounts proposed for the issue of multiple accusatives and some of the problems they raise. Section (5) motivates an analysis for adpositional accusatives as DPs that undergo more than one licensing operation. Section (6) contains the conclusions as well as some preliminary remarks about how the various types of DOM addressed here can be unified.

2. Objects and licensing. As mentioned above, both Gujarati as well as Romanian overtly indicate that more than one class of objects appears to undergo licensing. This is clear when a comprehensive picture of the morpho-syntactic behavior of objects is taken into account. We begin the presentation with Gujarati. Romanian is discussed in the next section.

2.1. GujARATI OBJECTS. Gujarati is a close relative of Hindi-Urdu but shows some differences with respect to the ways in which objects are encoded. We will be examining here the behavior of objects in the past perfective, given that object agreement (in gender and number) is overt in these contexts. Gujarati is an aspect-based split ergative language, where verbal agreement is normally controlled by the absolutive argument (see Mistry 1976, 1997, 2004, Magier 1983, Woolford 2006, Wunderlich 2012, Grosz and Patel-Grosz 2014 for Kutchi Gujarati, a.o.). In the 
sentences in (4) we can see subject agreeing absolutives, and in (5) we provide examples with object agreeing absolutives:

(4) Gujarati subject absolutive agreement (Mistry 1976: 3a-c, glosses adapted)
a. Ramesh
Ramesh(M)-ABS
'Ramesh came.' awy-o.
come.PFV-M.SG
b. Sudha
Sudha(F)-ABS
'Sudha came.'
awy-i.
come.PFV-F.SG
c. Balək
child(N)-ABS
awy-u.
come.PFV-N.SG
'A child came.'

(5) Gujarati object agreeing absolutives
a. Sudha-e
radio
khəridy- $O$.
Sudha(F)-ERG
$\operatorname{radio}(\mathrm{M})-\mathrm{ABS}$
buy.PFV-M.SG
'Sudha bought a radio.'
b. Sita-e
Sita(F)-ERG
kāgal
vacy-o.
letter(M)-ABS read.PFV-M.SG
'Sita read the letter.'
(Mistry 1976: 10a, glosses adapted)

Overt agreement is however not restricted just to absolutives. Similar to Hindi-Urdu (1)a, certain objects with grammaticalized humanness/animacy are morphologically signaled through an adposition which is homophonous with the dative marker. ${ }^{3}$ The important observation is that these special objects must show overt agreement. This is clearly illustrated in the examples below. The first example in (6) contains an ergative external argument and an adpositional differential object. As the two DPs have different genders, we can see that verbal agreement is controlled precisely by the feminine object. In the last two sentences in (6) the ergative external argument is feminine, while the differentially marked object is masculine. Agreement, once again, tracks the differential object.
Gujarati
a. Ramesh-e
Sudha-ne
Ramesh(M)-ERG
Sudha(F)-DAT=DOM
'Ramesh scolded Sudha.'
b. Sudha-e Ramesh-ne
Sudha(F)-ERG Ramesh(M)-DAT=DOM
'Sudha scolded Ramesh.'
c. Sita-e
$\operatorname{Sita}(\mathrm{F})$-ERG
'Sita harasses Raj.'
Raj-ne
dhəmkawy-i. pajavy-o.
scold.PFV-F.SG
(Mistry 1976: 14a, glosses adapted)
dhəmkawy- $o$.
scold.PFV-M.SG
(Mistry 1976: 14b, glosses adapted)
harass.PFV-F.SG

There are also instances of internal arguments that do not trigger agreement. For example, objects which are marked with a lexical dative only show up with a default neuter agreement

\footnotetext{
${ }^{3}$ Following the convention used above for Hindi-Urdu (1) and Spanish (2), we will label the animacy/specificity adposition as DAT=DOM. This is to capture the observation that objects differentially marked with an adposition exhibit non-trivial differences from datives. See however the next section for a brief presentation of an analysis (Manzini and Franco 2016) which takes the two classes to have the same syntax.
} 
form of the verb. This is illustrated in (7). Note moreover that if a clause contains both an absolutive argument as well as an adpositional differential object, it is the absolutive that will control agreement. In (8) the absolutive subject is singular, while the adpositional object is plural. The agreement inflection on the verb is singular, thus tracking the absolutive subject.

(7) Gujarati: non-agreeing datives (Mistry 1997: 6c; Woolford 2006: 41)

Kišor-(n)e kāgalone ado-v-ū hat- $u$.

Kishor(M)-ERG letter-DAT touch-DESID-N be.PST-N

'Kishor wanted to touch the letter.'

(8) Gujarati: absolutives and adpositional differential objects

$\begin{array}{lll}\text { Šeelaa pāāc mānas-o-ne } & \text { mokal-š- } e \text {. } \\ \text { Sheela(F)-ABS } & \text { five man-PL-DAT=DOM } & \text { send-FUT-SG } \\ \text { 'Sheela will send the five men.' } & \end{array}$

In the Indo-Aryan formal literature, it is well established that absolutives are types of structural Cases (Bhatt 2005, Woolford 2006, a.o.). Thus, their licensing has a purely structural basis. Overt agreement signals a relationship with a functional licenser in the clausal spine (most often, T). As already mentioned in the introduction, research on differential marking has reached the same conclusion with respect to the nature of the adpositional animacy introducer; a variety of diagnostics (among which the presence of overt agreement) indicate that the 'dative' adposition does not signal inherent or lexical marking, and that these objects also need a type of structural licensing. But given the data from Gujarati, the question is how to reconcile these two views. We see here two classes of objects which undergo licensing, but the morpho-syntactic reflexes of each operation are not identical. The picture from Gujarati is also not exceptional; other IndoAryan varieties show exactly the same facts (see Bhatt 2005, Wunderlich 2012, Manzini and Franco 2016, a.o.). Moreover, other adpositional differential object languages point toward the same conclusion (see also Ledgeway et al. 2017 for similar data from Romance).

3. Prepositional accusatives in Romanian. Just like in Gujarati, some types of objects must be introduced by the preposition PE in Romanian. ${ }^{4}$ Although object agreement is not overtly marked, these objects raise the exact same licensing problems as their Gujarati counterparts. The Romanian data are quite complex (Farkas 1978, Dobrovie-Sorin 1994, Cornilescu 2000, Mardale 2009, 2015, Tigău 2011, Hill 2013, a.o.) and have posed problems under most accounts; we will be giving here just the basic details which are relevant to the discussion. The pronoun in (9)a must be obligatorily introduced by the preposition; in (9)b we seen an animate DP that can also take the special marker. On the other hand, in canonical transitive sentences like (9)c the differential preposition is not well-formed with inanimates. For some speakers it gives rise to plain ungrammaticality, while some consultants marginally accept it if the DP is somehow upgraded, and highly specific. These examples confirm the observation that both Romanian and Gujarati are adpositional differential marking languages with sensitivity to humanness/animacy.

\footnotetext{
4 This marker is not homophonous with a dative. It is instead a locative preposition, as seen in the example in (1); the dative is inflectional, as illustrated in (2):

(1) A pus cartea pe masă. has put book.DEF.F.SG on table 'S/he has put the book on the table.'

(2) (I)-a dat cartea copilu-lui. CL.3.DAT-has given book.DEF.F.SG child-DAT.M.SG 'S/he has given the book to the child.'
} 
Romanian prepositional accusatives
a. *(Te)-a văzut *(pe) tine. $^{5}$
CL.2.ACC-has seen PE you.ACC
'S/he has seen you.'
b. A văzut-(o) (pe) fată.
has see-CL.F.SG.ACC PE girl
'S/he has seen the girl.'
c. A văzut-(o) (*pe) carte.
has seen-CL.F.SG.ACC PE book
'S/he has seen the book.'

The 'optionality' of PE in (9)b shows that animate DPs are not ill-formed if PE is missing. As expected, the example in (10) is also possible. ${ }^{6}$ Thus, Romanian is different from its relative, Spanish, where specific definite animates appear to be ungrammatical without $a$, see (2)a. This does not suggest however that animacy is optionally marked across the board. We have seen that pronouns are ungrammatical without PE, in their overt tonic form (9)a. Another example is provided by animate negative quantifiers which must take the preposition (11):
A văzut fata.
has seen girl.DEF.F.SG
'S/he has seen the girl.'
N-am văzut *(pe) nimeni/(*pe) nimic.
not-have seen PE nobody/ PE nothing
'I saw nobody/nothing'.

Third, the differential prepositional marker is also required in certain contexts irrespective of animacy. We mention below just two examples, from ellipsis and partitives. (12)a is ungrammatical without PE even if the understood antecedent is inanimate (see also Cornilescu 2000). Similarly, the D-linked wh-element in (12)b must use the preposition.
Differential prepositional mark
a. L-am văzut *(pe) acest-a ${ }^{7}$.
CL.3.M.SG.ACC-have 'I have seen this.'
b. $*(P e)$ care l-ai
PE which CL.3.M.SG.ACC-have seen
văzut?
'Which one did you see?'

\section{(animate or inanimate)}

\section{(animate or inanimate)}

\footnotetext{
${ }^{5}$ Note that pronouns must obligatorily take the accusative form. Nominative or dative inflection is ungrammatical with the differential preposition. Accusative clitic doubling is also obligatory in this context:

(1) *(Te) $/(*$ ţi $)$-a văzut pe *tu/*ţie. CL.2.ACC.SG/CL.2.DAT.SG -has seen PE you.NOM/you.DAT Intended: 'S/he has seen you.'

${ }^{6}$ Note that in Romanian the definite cannot be overt after a preposition, if the DP is unmodified. This accounts for the contrast between (9) and (10). Nevertheless, the noun is interpreted as definite in (9). For more details on the missing definite in Romanian, see Giusti (1994), or Dobrovie-Sorin (2007).

${ }^{7}$ The demonstrative must take the augmented form (that ends in $-a$ ) under ellipsis. As this morphology is normally only possible with a definite noun phrase, this type of demonstrative is assumed to have a definite interpretation. See especially Cornilescu and Nicolae (2012) for discussion.
} 
In most accounts the prepositional accusative in Romance languages signals a type of structural Case. For example, Dobrovie-Sorin (1994) proposes an analysis in terms of Kayne's Generalization (which will be briefly discussed in the next section). More recently, for López (2012) the Romance structural objects that take an obligatory preposition are exactly the categories that have an unvalued Case $[\mathrm{uC}]$ feature. We will see in the next section that there are some independent problems with both these accounts. What is relevant at this point is that other classes of DPs in Romanian have to be analyzed as signaling some type of structural licensing. We will be discussing here definite objects which receive a referential interpretation. ${ }^{8}$

One of the diagnostics for licensing refers to the obligatory presence of a specific morpheme even in contexts in which its 'canonical' meaning might not be obtained (López 2012, Wiltschko 2014, a.o.). It is known, since at least Belletti (1988), that some Romance objects are ungrammatical without the presence of an overt definite morpheme. This is the case of ECM constructions with non-finite adjectives, as in (13):

$\begin{array}{lll}\text { Consideră } & \text { miere* }(-a)^{9} & \text { foarte utilă pentru vindecarea multor afecţiuni. } \\ \text { considers } & \text { honey-DEF.F.SG } & \text { very helpful for curing many.GEN diseases } \\ \text { 'S/he considers (the) honey very helpful for the treatment of many diseases.' }\end{array}$

The obligatory presence of the definite is unexpected here, given that a mass noun like miere ('honey') can be normally used bare in object position. ${ }^{10}$ Note that the explanation cannot be that definiteness is forced here because the DP is the subject of a putative small clause. For one, this doesn't answer the question of why definiteness would be obligatory in the subject position. Second, a small clause account is not unchallenged for these constructions. For example, Williams (1983) argues that these structures represent complex predicates to which the DP object is merged compositionally. ${ }^{11}$ In fact, as Belletti's (1988) analysis implies, and as discussed by other researchers (see Manzini and Franco 2016, a.o.), the referential definite also signals a class that undergoes licensing. Therefore, the Romanian prepositional accusatives raise the same puzzle as their Gujarati counterparts, which we can call "the multiple accusatives puzzle"; saying that adpositional differential objects are categories that undergo licensing is not enough to distinguish them from other types of (structural) objects. The next section reviews some solutions various accounts have proposed for these data.

4. More than one accusative and how to tell them apart. The problem of multiple (structural) accusatives in the same language has been noticed before, and several solutions have been put forward. First and foremost, we are interested in examining accounts which acknowledge the presence of other classes signaling structural accusative besides prepositional objects. In the literature there are at least two possible explanations: i) Kayne's Generalization (Jaeggli 1982,

\footnotetext{
${ }^{8}$ Overt definites do not have only a referential interpretation in Romance languages. They can also act as expletives or can obtain readings of bound variables, more similar to indefinites. See Espinal and Cyrino (2017) for a recent discussion of these readings.

${ }^{9}$ As already seen in example (10) above, the definite has a suffixal nature in Romanian.

${ }^{10}$ See the Romanian example below:

(1) Mănâncă/cumpără/consideră miere. eats/buys/considers honey 'S/he eats/buys/considers honey.'

${ }^{11}$ For other problems with subjects of small clauses see Irimia (2018a, b).
} 
1986); ii) DOM as datives (Manzini and Franco 2016). We will be reviewing each of them in the following subsections.

4.1. KAYNE's GENERALIZATION. One of the earliest accounts for the Romance prepositional accusatives is in terms of the so-called Kayne's Generalization (see especially Jaeggli 1982, 1986). Under this condition the adposition is seen as a convergence mechanism needed in contexts where an object is clitic doubled. As the clitic 'absorbs' the Case assigning capacity of the licenser, the DP is left caseless. This would violate the Case Filter (Chomsky 1981), leading to ungrammaticality; the preposition is inserted as last-resort to check Case on the DP, and thus save the derivation. The general formulation of Kayne's Generalization is given below:

Kayne's Generalization (Jaeggli 1982: 20)

An object NP may be doubled by a clitic only if the NP is preceded by a preposition

The generalization can capture the fact that some languages can have more than one type of structural objects. The referential definite in Romance or the absolutive in Gujarati could result from Case assignment (licensing) from the regular licenser in one type of configuration. The adpositional arguments, while still require licensing, could be seen as representing a distinct Case checking configuration. The generalization can also easily derive examples like (9)a where the differential preposition is ungrammatical without clitic doubling (see also fn. 5). However, it has been shown not to hold in many other syntactic environments (see especially Sũner 1988, or Anagnostopoulou 2006). One the one hand, there are contexts in which the differential preposition is obligatory, but clitic doubling results in ungrammaticality. In Romanian, such contexts include the animate negative quantifier nimeni ('nobody'), as seen in (15) vs. (11)

\begin{tabular}{|c|c|}
\hline $\mathrm{Nu} \quad(* l)$-am & văzut *(pe) \\
\hline CL.3.M.SG.ACC-has & seen PE \\
\hline
\end{tabular}

On the other hand, the prepositional marker also appears to be obligatory (with the relevant classes of objects) in languages which do not have clitic doubling. Gujarati is one example. ${ }^{13,14}$

Given these (as well as other) counterarguments, Kayne's Generalization has been abandoned in its canonical form in (14), leaving the problem of multiple structural accusatives open. We propose, however, that one of its intuitions, namely that the differential adposition acts as a secondary licenser is useful and can derive the puzzles we are concerned with, but when understood in a slightly different way.

4.2. AdPositional dOM AS DATIVE. A recent account by Manzini and Franco (2016) proposes to resolve the "multiple accusatives" puzzle in a different way. The authors agree that certain classes such as the referential definite in Romance or the bare absolutive in Gujarati might encode structural/licensed objects. Also, based on various types of evidence, what is spelled out as the adpositional differential marker can be syntactically unified to (a type of ) datives. For Manzini and Franco (2016), both adpositional differential objects and (certain types of) datives encode an elementary predicate which introduces an inclusion/part-whole relation $(\subseteq)$, understood in terms

\footnotetext{
12 See Sũner (1988) or Dobrovie-Sorin (1990) for other examples.

${ }^{13}$ Even if we wanted to force a clitic nature of the absolutive agreement markers, Kayne's Generalization would still fail. We have seen that the absolutive agreement is possible without the adpositional marker.

${ }^{14}$ There is also the other side of the coin. There are languages which show clitic doubling but which do not have an adpositional differential marker. Extensive discussion is to be found in Anagnostopoulou (2006), a.o.
} 
of possession. The adapted bracketed diagram in (16)a indicates an indirect object dative, while that in (16)b depicts a differential object dative.

(16) Datives and DOM as the same class
a. gli parl-
he/she.DAT talk
DAT: ... [CAUS/ $v$ [parl- $[\mathrm{Q}(\subseteq) \mathrm{D} g l \mathrm{Q}(\subseteq) i]]] \quad$ (Manzini and Savoia 2016: 28b)
b. $\mathrm{mi}$ colp-
I. DAT/DOM hit
DOM: ...[CAUS/ $v$ [colp- $[\mathrm{Q}(\subseteq) \mathrm{D} m \mathrm{Q}(\subseteq) i]]] \quad$ (Manzini and Savoia 2016: 31)

This type of unification can straightforwardly derive the DOM/DAT homomorphism seen in Hindi-Urdu (1), Spanish (2) or Gujarati (6), as well as in other languages. ${ }^{15}$ But, as the authors notice themselves, there are also several diagnostics under which a unitary syntactic source for adpositional DOM and DAT is challenged. We have seen in (7) above that Gujarati verbs selecting for a lexical DAT dative cannot show overt object agreement. Indirect object datives behave similarly to lexical DAT when it comes to lack of agreement (see Mistry 1997 for examples). This is different from the adpositional DOM in the examples in (6), which does show overt agreement just like the object absolutives in (5). DOM and DAT are further distinguished under a variety of other diagnostics, such as hosting of secondary predicates, tolerance of nominalizations, etc. Turning now to Romanian, we also notice a split behavior of the datives and prepositional accusatives under many diagnostics, some of which are included in Table 1 (from Irimia 2018c). Moreover, there is no homomorphism either between the dative and the prepositional objects (as mentioned in fn. 4):

\section{Diagnostic ACC Prepositional ACC IO (DOM)}

\begin{tabular}{lccc}
\hline Morphology & & $\begin{array}{c}\text { Preposition }+ \text { accu- } \\
\text { sative (see fn. 5) }\end{array}$ & Dative case \\
$\begin{array}{l}\text { Mvt. and syntactic position } \\
\text { Sensitivity to animacy }\end{array}$ & A & B \\
$\begin{array}{l}\text { Hosting a reduced relative clause } \\
\text { Clitic doubling }\end{array}$ & $\sqrt{ }$ & $\sqrt{ }$ & $*$ \\
Sensitivity to specificity & $\sqrt{C C}$ & DAT \\
Passivization & $\sqrt{ }$ & $\sqrt{ }$ & $*$ \\
Controlling secondary predicates & $\sqrt{ }$ & $\sqrt{ }$ & (possible in re- \\
& & $*$ & stricted contexts) \\
Case retained under nominaliza- & $*$ & & $\sqrt{ }$ \\
tions & & & \\
\hline
\end{tabular}

Table 1: Differential objects and IO datives in Romanian

We notice here that DOM patterns more like regular accusatives under a variety of unrelated diagnostics. Under a unitary DOM/DAT syntax, it is not clear how these syntactic differences with respect to datives can be independently explained (see also Bárány 2018 for similar conclusions).

15 See also Bossong (1991) or Lazard (2001), a.o, for other examples. 
4.3. RAISING. Another recent account (López 2012) associates differential marking to a specific position in the clausal structure, as illustrated in (17). López (2012) only discusses the problem of multiple accusatives under one of its other facets - namely the difference between objects marked with a preposition, and objects which behave like predicates undergoing incorporation (and which do not normally show overt agreement). In this account, one possibility to address the multiple licensing accusatives would be to assume the existence of a yet different position for that variant of the accusative which does not take a preposition but shows agreement.

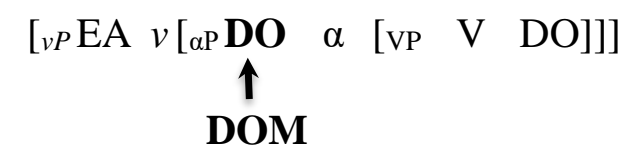

This option seems, however, difficult to implement for lack of unambiguous diagnostics. For the Gujarati agreeing absolutives in (6) one might assume raising. However, as Bhatt (2005) has noticed for the agreeing objects in Hindi-Urdu, "case licensing of objects is independent of the syntactic environment above the $v \mathrm{P}$ " (Bhatt $\mathrm{p}$. 764). The same conclusion is supported by Butt (1993). Lastly, for Woolford (2006) the agreeing absolutives (nominatives, in her terms) can trigger last-resort agreement when the subject is not available. But this formalization might also imply a position inside $v \mathrm{P}$. Thus, both DOM agreeing objects and non-DOM agreeing objects will have to be generated/interpreted inside $v \mathrm{P}$, and further distinguished in some other way. In any case, diagnostics that would help us tell apart the two structural objects are not easily available.

Turning now to Romanian, we notice that referential definite accusatives, as well as the prepositional accusatives do not seem to escape the $v \mathrm{P}$ under (some) binding tests. A position above $v \mathrm{P}$, as in (18)c, can only be ensured by clitic doubling (unsurprisingly, given what is known about clitic doubling, see especially Anagnostopoulou 2006). Thus, neither the object in (18)a or the one in (18)a can bind a pronoun inside the external argument, indicating that (at least) in these configurations the object is not higher than the EA.

Structural object positions in Romanian
a. Părinţii lor $*_{i} / j$ au lăudat copii- $i_{i}$. parents their have praised children-DEF.N.PL 'Their parents have praised the children.'
b. Părinţii lor $*_{\mathrm{i} / \mathrm{j}}$ au lăudat pe copii ${ }_{\text {. }}$. parents their have praised PE children-DEF.N.PL 'Their parents have praised the children.'
c. Părinţii lor ${ }_{\mathrm{i} / \mathrm{j}} i$-au lăudat pe copii ${ }_{\text {. }}$. parents their CL.N.PL.ACC-have praised PE children-DEF.N.PL 'Their parents have praised the children.'

Other diagnostics are volatile and might not in fact support any type of raising for structural objects that are not clitic doubled. Thus, it follows that prepositional DOM and other licensed accusatives must be distinguished in other ways. We propose that the adpositional differential objects are categories that contain more than one feature that require licensing, and thus they undergo more than one licensing operation. The details of the analysis are given in the next section.

5. Prepositional accusatives and secondary licensing. The analysis sketched here is based on several assumptions. First, we follow the general idea of nominal licensing, in the sense that DPs enter into a relationship with functional heads $(v, \mathrm{~T}, \mathrm{C}$, etc.) in the clausal spine. Second, the strict adaptation we make is that licensing is relativized to features (besides its sensitivity to 
domains), and not just to the categorial status as DP (as opposed to NP). ${ }^{16}$ This modification has two main consequences: i) not all features of a DP need to be licensed in the same way; ii) a DP may contain more than one feature that requires licensing. Thus, the same DP can be subject to more than one licensing operation such as all the relevant features can get valued (see also Béjar and Rezac 2009). Regarding the implementation of licensing itself, we use here the basics of the Agree operation in minimalist syntax (following Chomsky 2001, et subseq.), although nothing hinges on this; the mechanics can be executed under many other frameworks and accounts.

Third, the type of licensing we are dealing with here must apply obligatorily; absolutive objects do not seem to be well-formed if agreement is missing in Gujarati. Similarly, in both Romanian and Gujarati if the prepositional marker is omitted in the relevant contexts, the result is normally ungrammaticality. This seems to indicate that not all feature valuation is crash proof and might not fail (see also Kalin to appear for a similar view, but Preminger 2014 for fallible Agree operations). Forth, as already mentioned, we adopt one intuition from Kayne's Generalization, namely that in certain conditions, (certain features of) DPs need a secondary licenser, when the primary licenser is not available anymore. The obligatory preposition signals precisely the presence of this secondary licenser in the same domain ${ }^{17}$. And fifth, based on previous remarks along the same lines (Richards 1998, Cornilescu 2000, Harley and Ritter 2002, Adger and Harbour 2007, a.o.), we connect animacy/humanness to the presence of a [+PERSON] feature, when merged on a category which introduces gender (see also Cornilescu 2000). Table 2, based on Harley and Ritter (2002) is a step towards the formalization of animacy.

\begin{tabular}{ll} 
PERSON/ANIMACY & FEATURES \\
\hline $1^{\text {st }}$ person & {$[+$ PERSON] [+PARTICIPANT $]$ (speaker) } \\
$2^{\text {nd }}$ person & {$[+$ PERSON] [+PARTICIPANT $]$ (addressee) } \\
$3^{\text {rd }}$ person & {$[+$ PERSON] } \\
{$[+$ human,+ animate $]$} & \\
\hline
\end{tabular}

Table 2: Person and animacy (building on Harley and Ritter 2002)

With these tools in hand, we are now ready to address the problematic adpositional accusative patterns under investigation. Let's start with the Gujarati agreeing absolutives in (5). As these objects tend to interpreted specific, we assume that these DPs contain a [+specific] feature which must be licensed in the clausal syntax. Following Bhatt (2005), the main licenser is $\mathrm{T}^{0}$ :

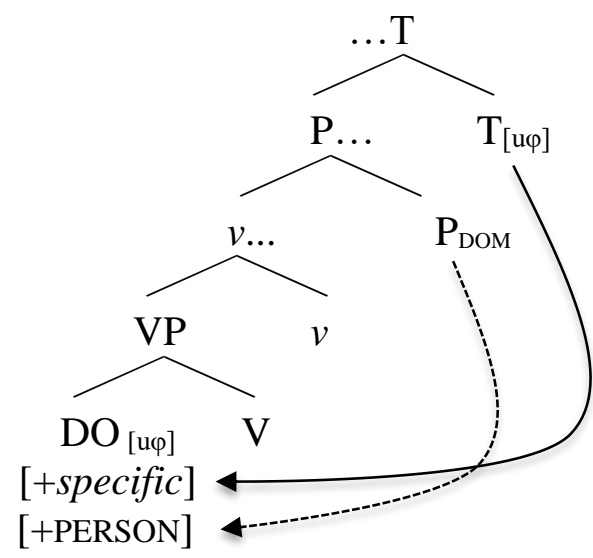

\footnotetext{
${ }^{16}$ For relativization to domains, see especially Baker (2015).

${ }^{17}$ See also Ledgeway et al. (2017) for similar remarks from Southern Italian varieties.
} 
The contexts in (6), on the other hand, signal DPs that contain more than one feature that requires licensing, namely [+specific] and [+PERSON]. As [+PERSON] must enter into a relationship with a licenser in the clausal spine, it can only do so when the nominal escapes incorporation. Under incorporation, the nominal (which would rather behave as a predicate, of type $\langle\mathrm{e}, \mathrm{t}\rangle$ ) will form a complex with the verb, thus becoming invisible for clausal licensers. If [+PERSON] happens to be found on a gender-introducing category in a nominal that undergoes incorporation, the derivation will crash, as [+PERSON] will not be visible to the relevant licensers outside the predicate complex. This indicates that the merge of the [+specific] feature actually creates a DP, that is a category that cannot undergo incorporation (and is not of type $<e, t>$ ). The creation of a category that escapes incorporation will provide [+PERSON] with the opportunity to get licensed. However, at least in some languages, a complication is given by the fact that [+specific] itself requires licensing. As licensers can only value one feature at a time, the second feature will need an additional licenser in these contexts. As already mentioned, the presence of the secondary licenser is signaled by the obligatory presence of the preposition. Thus, adpositional differential marking in Gujarati and Romanian can be characterized as in (20):

Adpositional differential marking: If a DP has more than one feature (of the same type) that requires valuation in the same domain, an additional licenser must be made available

The same reasoning can be assumed, in its basics, for Romanian. The only difference resides in the typology of features seen in secondary licensing configurations. Following Longobardi (2008), a.o., referential definiteness is also connected to a [+PERSON] feature. We assume that the various interpretations of [+PERSON] result from the various positions it can merge to in the nominal structure (see also Irimia 2018a). When found in D, [+PERSON] is read as referential definiteness. As [+PERSON] needs valuation, the sentential configuration must contain a licenser for referential definite DPs. When the DP also contains [+PERSON] on a category that introduces (grammatical) gender, a supplementary licenser must be recruited. Thus, the relevant classes of objects will show an obligatory preposition.

Romanian also provides indication about the way in which secondary licensers are restricted. The general rule seems to be that a domain can contain only one supplementary licenser. If there are yet other features that require licensing, they will need to be addressed in a different domain. Clitic doubling is the relevant category here, as we noticed in the contrast between (18)a, b and (18)c. The latter contains a referential definite ${ }^{18}$, the prepositional differential marker, as well as clitic doubling. The clitic is interpreted (thus licensed) higher than the $v \mathrm{P}$, thus the binding test goes through. Note that the clitic carries obligatory accusative inflection, thus the idea of licensing is not without basis for this category. The same facts hold in other languages that contain a three-way specification of DPs, such as Romance varieties that show overt past participle agreement, the differential preposition, as well as clitic doubling.

Another welcome result of this analysis is that it can also predict the presence of the differential marker on less discussed, non-canonical contexts, where animacy/specificity are overridden. Other categories might introduce definiteness (and thus [+PERSON]), among which demonstratives or ellipsis, and can be found in configurations where one [+PERSON] feature is already present.

6. Conclusions and further remarks. The analysis proposed here uses an articulated decomposition of the DP featural make-up and explores its interaction with licensing. It also builds on the

\footnotetext{
18 See fn. 6.
} 
intuition that in languages like Gujarati or Romanian, the prepositional marker does not simply indicate the difference between classes that do not need licensing/are caseless (the non-differentially marked ones) and classes that need licensing (the prepositional accusatives). The account can also avoid the problems raised by the alternative accounts reviewed above.

The obvious question is what type of predictions are made with respect to languages where there is no overt indication of secondary licensing. For example, in Hindi-Urdu, there are absolutives which trigger overt agreement, but the differentially marked objects cannot show overt agreement. Does this imply that the adpositional marker only signals licensing, but not secondary licensing? Although the data need more attention, the secondary licensing account could still be maintained under the assumption that the spell-out of agreement features is blocked by the presence of a preposition (see also Atlamaz and Baker to appear). This would also explain why overt agreement is also blocked with the ergative postposition in Hindi-Urdu, as opposed to Gujarati.

Turning to Spanish, we have seen that referential definites which are also animate are not possible without the differential preposition. This observation has been taken to motivate the idea of licensing for the adpositional objects. However, saying that the differential objects are the only classes that undergo licensing would be problematic in contexts similar to (13), and more generally in configurations where definitenesss is obligatory irrespective of animacy. One promising path is understanding how two [PERSON] features interact in the same domain, and how complex probes are parametrized in the realm of differential marking.

\section{References}

Adger, David and Daniel Harbour. 2007. The syntax and syncretisms of the Person Case Constraint. Syntax 10(1): 2-37. https://doi.org/10.1111/j.1467-9612.2007.00095.x.

Aissen, Judith. 2003. Differential object marking: iconicity vs. economy. Natural Language and Linguistic Theory 43 (4): 591-614. https://doi.org/10.1023/A:1024109008573.

Anagnostopoulou, Elena. 2006. Clitic doubling. In Martin Everaert and Henk van Riemsdjik (eds.), The Blackwell companion to syntax. 519-581. Amsterdam: John Benjamins.

Atlamaz, Ümit and Mark Baker. to appear. Agreement with and past oblique subjects: New considerations from Kurmanji. Syntax.

Baker, Mark. 2015. Case: its principles and parameters. Cambridge: Cambridge University Press.

Bárány, András. 2018. DOM and dative case. Ms.

Béjar, Susana and Milan Rezac. 2009. Cyclic Agree. Linguistic Inquiry 40(1): 35-73. https://doi.org/10.1162/ling.2009.40.1.35.

Belletti, Adriana. 1988. The case of unaccusatives. Linguistic Inquiry 19(1): 1-34. http://www.jstor.org.myaccess.library.utoronto.ca/stable/4178572.

Bossong, Georg. 1991. Differential object marking in Romance and beyond. In D. Kibbee and D. Wanner (eds.), New analyses in Romance linguistics. 143-170. Amsterdam/Philadelphia: John Benjamins.

Bossong, Georg. 1998. Le marquage différentiel de l'object dans les langues de l'Europe. In Feuillet, Jack (ed.), Actance e valence dans les langues d'Europe. 193-259. Berlin/New York: Mouton de Gruyter.

Bhatt, Rajesh. 2005. Long distance agreement in Hindi-Urdu. Natural Language \& Linguistic Theory. 23(4): 757-807. https://doi.org/10.1007/s11049-004-4136-0.

Bhatt, Rajesh and Elena Anagnostopolou. 1996. Object shift and specificity: evidence from kophrases in Hindi. In Lisa M. Dobrin, Kora Singer and Lisa McNair (eds.), Papers from the 
$32^{\text {nd }}$ regional meeting of the Chicago Linguistic Society. 11-22. Chicago: Chicago Linguistic Society.

Butt, Miriam. 1993. Object specificity and agreement in Hindi-Urdu. In Catharine Beals et al. (eds.), Papers from the $29^{\text {th }}$ regional meeting of the Chicago Linguistic Society. 89-103. Chicago: Chicago Linguistic Society.

Butt, Miriam. 1995. The structure of complex predicates in Urdu. CSLI Publications. Stanford: CA.

Chomsky, Noam. 1981. Lectures in government and binding. Dordrecht: Foris.

Chomsky, Noam. 2001. Minimalist inquiries: the framework. In Roger Martin, David Michaels, Juan Uriagereka and Samuel Jay Keyser (eds.), Step by step: Essays on minimalist syntax in honor of Howard Lasnik. 89-155. Cambridge, MA: MIT Press.

Comrie, Bernard. 1979. Definite and animate direct objects: a natural class. Linguistica Silesiana 3 (Katowice: University of Silesia). 13-21.

Comrie, Bernard. 1981. Language universals and linguistic typology. Oxford: Basil Blackwell.

Cornilescu, Alexandra. 2000. On the interpretation of the prepositional accusative in Romanian. Bucharest Working Papers in Linguistics 2: 91-106.

Cornilescu Alexandra and Alexandru Nicolae. 2012. Nominal ellipsis as definiteness and anaphoricity: The case of Romanian. Lingua 122(10): 1070-1111.

https://doi.org/10.1016/j.lingua.2012.05.001

Croft, William. 1988. Agreement vs. case marking and direct objects. In Michael Barlow and Charles A. Ferguson (eds.), Agreement in natural language. Approaches, theories, description. 159-180 Stanford, CA: CSLI Publications.

Croft, William. 1990. Typology and universals. Cambridge: Cambridge University Press.

Darlymple, Mary and Irina Nikolaeva. 2011. Objects and information structure. Cambridge: Cambridge University Press.

Dobrovie-Sorin, Carmen. 1990. Clitic doubling, wh-movement and quantification in Romanian. Linguistic Inquiry 21(3): 351-397. http://www.jstor.org/stable/4178681.

Dobrovie-Sorin, Carmen. 1994. The syntax of Romanian. Comparative studies in Romance. Berlin/New York: Mouton de Gruyter.

Dobrovie-Sorin, Carmen. 2007. Article drop in Romanian and extended heads. In Gabriela Alboiu, Andrei Avram, Larisa Avram and Daniela Isac (eds.), Pitar Moş: a building with a view. Papers in honor of Alexandra Cornilescu. 99-107. Bucureşti: Editura Universităţii din Bucureşti.

Espinal, M. Teresa and Sonia Cyrino. 2017. The definite article in Romance expletives and long weak definites. Gossa 2(1), 23: 1-26. https://doi.org/10.5334/gjgl.160.

Farkas, Donka. 1978. Direct and indirect object reduplication in Romanian. Donka Farkas, Wesley M. Jacobsen, and Carol W. Todrys (eds.), In Papers from the $14^{\text {th }}$ Regional Meeting of the Chicago Linguistic Society. 88-97. Chicago: Chicago Linguistic Society.

Giusti, Giuliana. 1994. Enclitic articles and double definiteness: a comparative analysis of nominal structure in Romance and Germanic. The Linguistic Review 11(3-4): 241-

255. https://doi.org/10.1515/tlir.1994.11.3-4.241.

Givón, Talmy. 1984. Direct objects and dative shifting: Semantic and pragmatic case. In Frans Plank (ed.), Objects. Towards a theory of grammatical relations. 151-183. London: Academic Press. 
Grosz, Patrick and Pritty Patel-Grosz. 2014. Agreement and verb types in Kutchi Gujarati. In Pritha Chandra and Richa Shrishti (eds.), The lexicon-syntax interface. Perspectives from South Asian languages. 217-243. Amsterdam/Philadelphia: John Benjamins.

Harley, Heidi and Elizabeth Ritter. 2002. Person and number in pronouns: a feature-geometric approach. Language 74(3): 482-526. http://dx.doi.org/10.1353/lan.2002.0158.

Hill, Virginia. 2013. The direct object marker in Romanian: a historical perspective. Australian Journal of Linguistics 33(2): 140-151. https://doi.org/10.1080/07268602.2013.814527.

Irimia, Monica Alexandrina. 2018a. Types of structural objects. Some remarks on the Romanian prepositional accusative. Ms.

Irimia, Monica Alexandrina. 2018b. Decomposing DOM. Ms.

Irimia, Monica Alexandrina. 2018c. Prepositional accusatives and datives are not a homogeneous class in Romanian. Ms.

Jaeggli, Osvald. 1982. Topics in Romance syntax. Dordrecht: Foris.

Jaeggli, Osvald. 1986. Three issues in the theory of clitics: case, doubled NPs and extraction. In Borer, Hagit (ed.), Syntax and semantics 19: the syntax of pronominal clitics. 15-42. Orlando, FL: Academic Press.

Kalin, Laura. to appear. Licensing and differential object marking. The view from Neo-Aramaic. Syntax. available at: https://www.laurakalin.com/papers-handouts/.

Kayne, Richard. 1975. French syntax. The transformational cycle. Cambridge, MA: MIT Press. Lazard, Gilbert. 2001. Le marquage différentiel de l'object. In Martin Haspelmath, Ekkehard König, Wulf Österreicher \& Wolfang Raible (eds.), Language typology and linguistic universals. An international handbook, vol. 2. 873-885. Berlin/New York: Mouton de Gruyter.

Ledgeway, Adam, Norma Schifano and Giuseppina Silvestri. 2017. Differential object marking and the properties of $D$ in the dialects of the extreme South of Italy. Ms.

Levin, Ted. 2017. On the nature of differential object marking. Insights from Palauan. Ms.

Lochbihler, Bethany. 2012. Aspects of argument licensing. Montreal: McGill University doctoral dissertation.

López, Luis. 2012. Indefinite objects. Scrambling, choice functions and differential marking. Cambridge, MA: MIT Press.

Magier, David. 1983. Topics in the grammar of Marwari. Berkeley: University of California doctoral dissertation.

Manzini, M. Rita and Ludovico Franco. 2016. DOM and goal datives. Natural Language \& Linguistic Theory. 34(1): 197-240. https://doi.org/10.1007/s11049-015-9303-y.

Mardale, Alexandru. 2009. Un regard diachronique sur le marquage différentiel de l'object en roumain. Revue Roumaine de Linguistique LIV (1-2): 65-93.

Mardale, Alexandru. 2015. Differential object marking in the first original Romanian texts. In Virginia Hill (ed.), Formal Approaches to DPs in Old Romanian. 200-245. Leiden/Boston: Brill.

Mistry, P. J. 1976. Subject in Gujarati: An examination of verb agreement phenomenon. In M. Verma (ed.), The notion of subject in South Asian languages. 240-268. Madison, WI: University of Wisconsin.

Mistry, P. J. 1997. Objecthood and specificity in Gujarati. In J. Hill, P.J. Mistry and L. Campbell (eds.), The life of language. 425-442. Berlin: Mouton de Gruyter.

Mistry, P. J. 2004. Subjecthood of non-nominatives in Gujarati. In Peri Bhaskararao and Karumuri Venkata Subbarao (eds.), Non-nominative subjects. Vol. 2, 1-32. Amsterdam: John Benjamins. 
Mohanan, Tara. 1994. Argument structure in Hindi. Stanford, CA. CSLI Publications.

Moravcsik, Edith A. 1978. On the case marking of objects. In Joseph H. Greenberg, Charles A. Ferguson \& Edith A. Moravcsik (eds.), Universals of human language. Syntax. Volume IV, 249-289. Stanford, CA: Stanford University Press.

Ormazabal, Javier and Juan Romero. 2007. The object agreement constraint. Natural Language \& Linguistic Theory 25(2). 315-347. http://dx.doi.org/10.1007/s11049-006-9010-9.

Ormazabal, Javier and Juan Romero. 2013. Differential object marking, case and agreement. Borealis: An international Journal of Hispanic Linguistics 2(2). 221-239. http://dx.doi.org/10.7557/1.2.2.2808.

Preminger, Omer. 2014. Agreement and its failures. Cambridge, MA: MIT Press.

Richards, Marc. 1998. Defective Agree: Case alternations, and the prominence of Person. In Marc Richards and Andrej L. Machukov (eds.), Linguistische Arbeits Berichte (Volume on Scales). Volume 86, 137-161. Universität Leipzig.

Suñer, Margarita. 1988. The role of agreement in clitic-doubling constructions. Natural language and linguistic theory. http://www.jstor.org/stable/4047651.

de Swart, Peter. 2007. Cross-linguistic variation in object marking. Radbound: University of Nijmegen doctoral dissertation.

Tigău, Alina M. 2011. Syntax and interpretation of direct objects in Romance and Germanic languages. Bucureşti: Editura Universităţii din Bucureşti.

Williams, Edwin. 1983. Against small clauses. Linguistic Inquiry 19(1). 1-34. http://www.jstor.org/stable/4178326.

Wiltschko, Martina. 2014. The universal structure of categories. Towards a formal typology. Cambridge: Cambridge University Press.

Woolford, Ellen. 2006. Case agreement mismatches. In Boeckx, Cedric (ed.), Agreement systems. 299-316. Amsterdam/Philadelphia: John Benjamins.

Wuderlich, Dieter. 2012. Case and agreement variation in Indo-Aryan. Ms available on author's webpage: http://www.zas.gwz-berlin.de/fileadmin/mitarbeiter/wunderlich/Case_and_agreement_variation_in_Indo-Aryan.pdf. 